\title{
The Landlady from Hell. The Iconography of the Medieval Wall Paintings in Rimavské Brezovo and Liptovské Sliače
}

\author{
Peter MEGYEŠI
}

\begin{abstract}
The text deals with the iconography of the medieval wall paintings in the churches in Rimavské Brezovo and Liptovské Sliače. Both of these paintings of female figures holding vessels and beset by demons represent the specific motif of a landlady or tavern keeper suffering in Hell. Depictions of the figure of the landlady in combination with demons can be found throughout medieval Europe from the early $14^{\text {th }}$ century until the early modern period, and negative portrayals of the character appear in numerous literary sources of the period. The preserved paintings in Rimavské Brezovo and Liptovské Sliače are valuable evidence of eschatological concepts and the ways in which they were disseminated in the $14^{\text {th }}$ and $15^{\text {th }}$ centuries.
\end{abstract}

Keywords: Rimavské Brezovo, Liptovské Sliače, Middle Ages, Wall painting, Iconography, Eschatology, Last Judgement

In 2016 a series of medieval wall paintings were uncovered and restored in the nave of the Evangelical Church in Rimavské Brezovo (Rimabrézó in Hungarian) which has deepened our understanding of the previously known and discussed paintings in the church interior. ${ }^{1}$ The original early Gothic single-nave church was built in the first half of the $14^{\text {th }}$ century and featured a rectangular chancel roofed with a cross vault, a sacristy on the northern side and a western tower. In 1893 the nave was extended to the south by demolishing the southern wall of the original Gothic nave, reorienting the church in a north-south direction and transforming the inter-

\footnotetext{
This text is adapted from the paper "Krčmárka z pekla $\mathrm{K}$ ikonografii stredovekej nástennej mal'by v Rimavskom Brezove [The Landlady from Hell - the iconography of the medieval wall paintings in Rimavské Brezovo]" which was presented at the 4th Annual "Recent Findings from Research on the Medieval Monuments of the Gothic Route" Conference held in Rožňava on $27^{\text {th }}$ August 2020.

The results were presented by Miroslav Janšto and Rudolf Boroš: “Ev. a. v. kostol v Rimavskom Brezove - výsledky
}

nal arrangement, with the original chancel taking on the function of an eastern side chapel. ${ }^{2}$

The medieval wall paintings are preserved mainly on the internal walls of the former chancel. The painted decorations were executed in horizontal bands around the entire perimeter of the structure. On the lower part of the wall is a level with illusory hanging drapery, above which is a register with half-figures of the Prophets in quatrefoils with illusory panelling. The walls of the chancel are dedicated to paintings with a Marian theme. On the northern wall is a large painting of the Death of the Virgin Mary, above which is a register with a painting of

reštaurátorského výskumu a obnovy interiéru [The Evangelical Church in Rimavské Brezovo - results of the conservation research and the restoration of the interior]" at the 3rd Annual "Recent Findings from Research on the Medieval Monuments of the Gothic Route" Conference held in Rožňava on 30-31 August 2018.

2 TOGNER, M.: Stredoveká nástenná malba v Gemeri. Bratislava 1989, p. 182. 


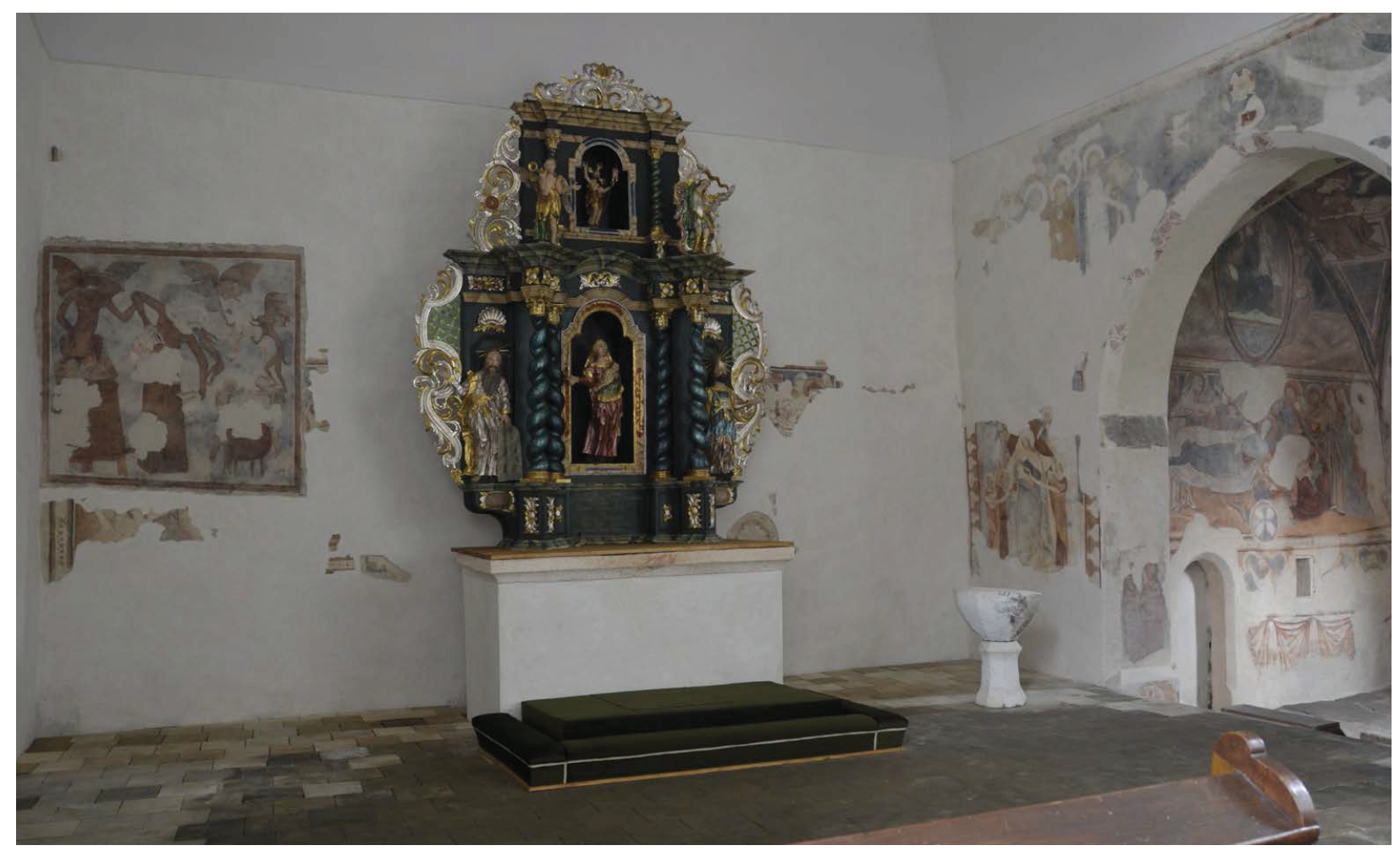

Fig. 1: Interior of the Evangelical Church in Rimavsee Brezovo, Wall painting The Landlady in Hell in the western part of the north wall of the nave, beginning of the 14th century. Photo: Miroslav Jansto.

the Assumption. In the upper part of the east wall of the chancel there is a fragment of a scene around the edges of the window in which traces of a mandorla surrounded by angels with musical instruments can be discerned. Other images can be identified among the other scenes in the sanctuary, including a depiction of the Coronation of the Virgin Mary. Below this scene there is an Adoration of the Magi which is divided into two sections by a window. On the south wall there are scenes of the Presentation of Christ in the Temple and the Descent from the Cross. The panels of the vaulting of the chancel feature a Christ Blessing in a mandorla surrounded by the Sun, the Moon

\footnotetext{
3 Ibidem, p. 182. PROKOPP, M.: Középkoori freskók Gömörben. Somorja 2002, pp. 76-82. PLEKANEC, V. - HAVIAR, T. Gotický Gemer a Malohont. Italianizmy v stredovekej nástennej mal'be. Martin 2010, pp. 160-171.

4 Bread can be seen in the bowl in the Weighing of Souls scene, serving as a saving weight. For more on the identification
}

and stars, four figures of the Fathers of the Church seated beside pulpits, angels with inscribed ribbons and the symbols of the Four Evangelists. On the inner walls of the triumphal arch are the figures of two Apostles. ${ }^{3}$ On the southern side of the triumphal arch facing the nave there are fragmentary paintings depicting Christ in a mandorla, a blessing angel with an inscribed ribbon and St Bartholomew carrying a stick from which his flayed skin is suspended. The north side of the triumphal arch features a scene with St Anna accompanied by saints, likely a depiction of the Holy Kinship. Fragments of a composition of the Weighing of Souls survive on the southern wall. ${ }^{4}$

and interpretation of this specific iconography, see CIPOVOVÁ M. - MEGYEŠI, P.: Chlieb ako spásonosné závažie. K stredovekej ikonografii Váženia duší. In: Ars, 49, 2016, No. 2, pp. 164-171. MEGYEŠI, P.: Metódy a pojmy interpretácie stredovekých obrazov: nástenné mal'by v Kraskove. In: Algoritmy obrazov - obrazy algoritmov. K povahe výskumov v súčasnom umení. Eds. GERÁT, I. - ZERVAN, M. Bratislava 2019, pp. 22-37. 


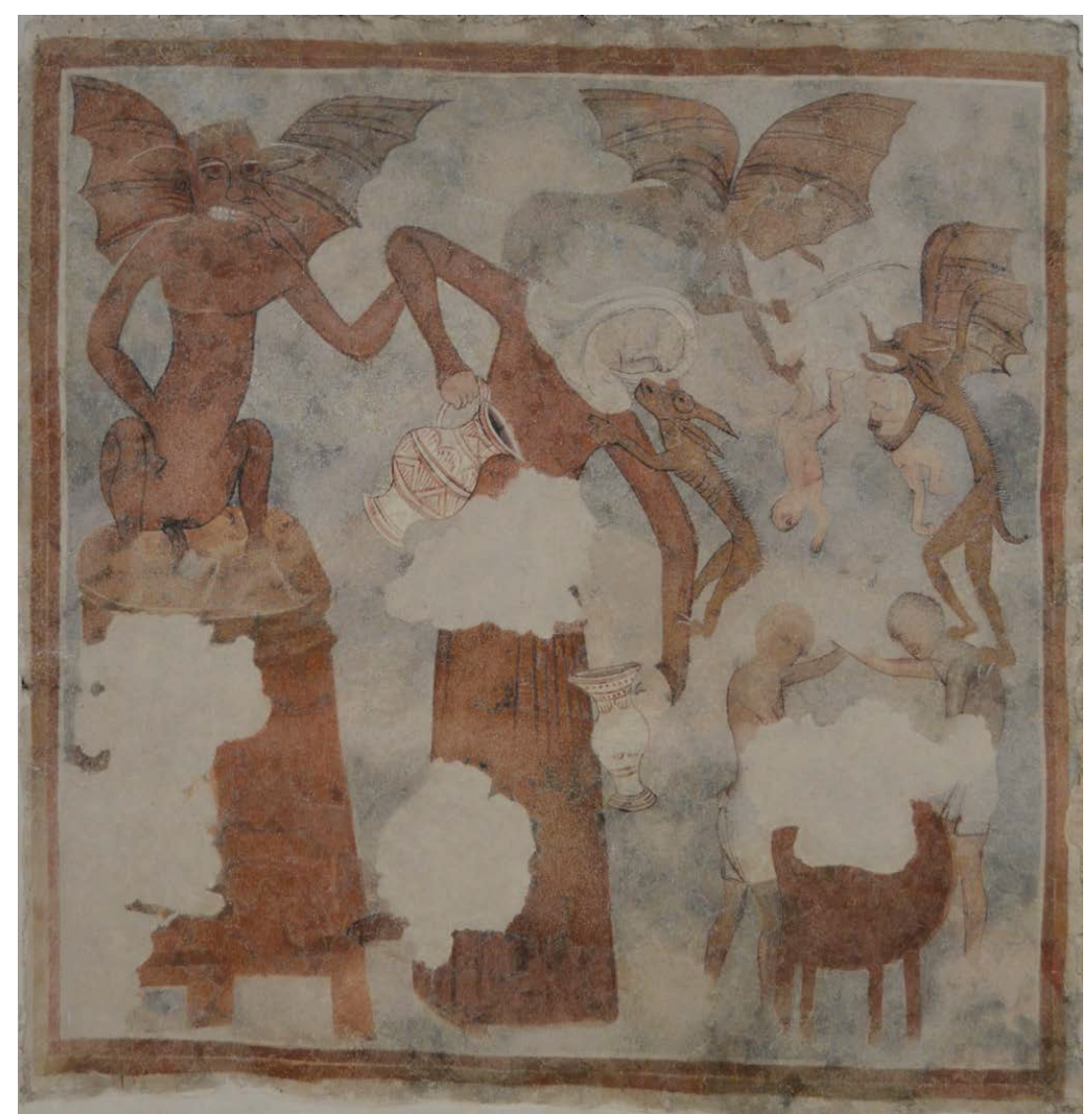

Fig. 2: The Landlady in Hell, the beginning of the 14th century, Wall painting, Rimavské Brezovo, Interior of the Evangelical Church in Rimavské Brezovo, the western part of the north wall of the nave. Photo: Miroslav Jansto.

On the north wall of the nave there are elements of a Passion cycle, more specifically Christ Carrying the Cross and the Crucifixion. Milan Togner argued that the entire decorative scheme of the church in Rimavské Brezovo could be attributed unambiguously to the workshop of the Master of the Ochtiná Presbytery and dated the works to the period between 1360 and $1380 .{ }^{5}$ When writing his monograph, however, the Czech academic was unaware of the wall paintings which would later be discovered on the triumphal arch from the side of the nave and on the north and south walls of the nave.

This brief contribution is intended to clarify the iconography of the paintings on the western part of the north wall of the nave which were uncovered

\footnotetext{
5 TOGNER 1989 (see in note 2), p. 182.
}

and restored in 2016. [Fig. 1] The scene which is bordered by an illusory frame does not belong within the Christological and Marian cycle but is instead part of an older layer of paintings connected with the consecration of the church which can be dated to the beginning of the $14^{\text {th }}$ century. [Fig. 2] Even at first glance the painting draws our attention due to its unusual theme: a woman in a red dress with a white hood upon her head pours liquid from a ceramic flask in her right hand to another vessel which she is holding in her left hand. The colour, shape and decoration of the vessels depicted in the wall painting corresponds to the so-called white painted Gemer ceramic style which was typical for this region in the $14^{\text {th }}$ and $15^{\text {th }}$ centuries. ${ }^{6}$ The

6 We would like to thank the archaeologist Alexander Botoš for bring this fact to our attention. BOTOŠ, A.: Hrnčiar- 


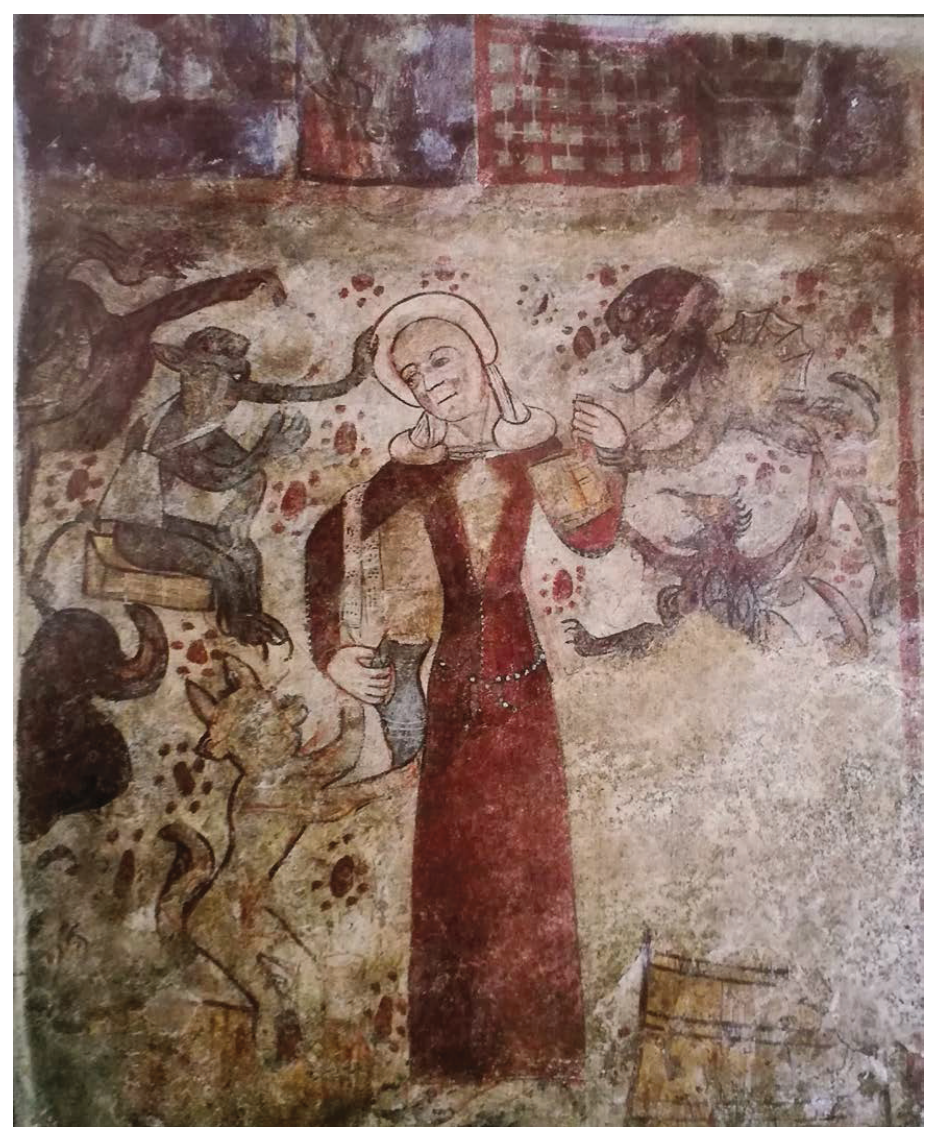

Fig. 3: The Landlady in Hell, c.1400, Wall painting, Liptovské Sliace, the Church of St Simon and Judas, the north wall of the nave. Repro: Biathová, K.: Maliarske prejavy stredovekébo Liptova. Bratislava 1983.

woman is being attacked by demonic creatures with a demonic appearance, one of which, comparable in size with the attacked woman, has membranous wings, a pointed nose and ears, a sharp-toothed grin with a protruding tongue, and a piercing stare. The creature is squatting over a barrel into which it appears to be defecating. It has seized the woman's left arm at the elbow as if attempting to prevent her from pouring the liquid. A second creature has the zooformic appearance of an emaciated four-legged animal featuring a head with large protruding eyes and long pointed ears. This demonic creature is also attacking the woman - it has jumped onto her left arm, bringing its jaws uncomfortably close to her

stvo na území Novohradu a Gemer-Malohontu v období stredoveku a včasného novoveku. In: Zbornik zo stretnutia priatel'ov regionálnej histórie. Ed. ŠESTÁK, M. Hradište face, and is digging the sharp claws of its hind paws into her arm. In the background of the scene, we can see another two demons who are tormenting two naked human figures as they dangle in the air. Below these demons, two other human figures are shown standing opposite each other over either a cauldron or a table. The two figures are grasping each other's heads in their hands, but this section of the painting is damaged and the exact activity of the two figures cannot be clearly identified. The composition of the female figure attacked by demons in combination with the events in the background immediately evokes the sense that the scene contains a moralising aspect.

2017, pp. 51-60. HOŠŠS, J.: Prehl'ad vývoja stredovekej keramiky na Slovensku. In: Archaeologia historica, 8, 1983, pp. 215-232. 
Among the extensive collection of surviving medieval wall paintings in Slovakia we can find only a single analogy to this unorthodox work - a painting from around 1400 in the Church of St Simon and Judas in Liptovské Sliače (Háromszlécs in Hungarian). [Fig. 3] Here too we can see a woman in a red dress with a white hood upon her head who is pouring liquid from one vessel to another while being tormented by demons. While academic studies of the painting have generally considered the work as interesting and unique, there is little agreement over the possible interpretation of the imagery and the suggestions offered to date have been somewhat unconvincing. Josef Krása perceives the Liptovské Sliače work as a fragment of a moralising cycle. ${ }^{7}$ Karel Stejskal has described the image as an interesting allegory of gluttony from the Seven Cardinal Sins cycle. ${ }^{8}$ However, the scene is framed as an individual work and, as with the painting from Rimavské Brezovo, it is not accompanied by other related scenes which would confirm Krása and Stejskal's theory of the existence of a more extensive painting composition, either as a morality cycle or as a series of the Seven Cardinal Sins. Katarína Biathová has characterised the painting as a scene of an urban type of morality, more specifically one of the Seven Vices, but also noted that it was unusual for such a scene to be found in such a traditional and provincial setting. According to Biathová, the presence of the scene can be attributed to its proximity to Ružomberok and Partizánska L’upča, emphasising that the church in Liptovské Sliače was not associated with a local landowner but, together

\footnotetext{
KRÁSA, J.: Levočské morality. In: Zo starš̌ch výtvarných dejín Slovenska. Ed. VÁROSS, M. Bratislava 1965, p. 246.

8 STEJSKAL, K.: Liptovské Sliače. In: Stredoveká nástenná malba na Slovensku. Eds. DVOŘÁKOVÁ, V. - KRÁSA, J. - STEJSKAL, K. Bratislava 1978, p. 143.

9 BIATHOVÁ, K. Maliarske prejayy stredovekého Liptova. Bratislava 1983, p. 20.

${ }^{10}$ PROKOPP, M.: Italian Trecento Influence on Murals in East Central Europe, Particulary Hungary. Budapest 1983, p. 154.

${ }^{11}$ TOGNER, M.: Stredoveká nástenná mal'ba na Slovensku. Súčasný stav poznania (Addenda et corrigenda). Bratislava 1988, p. 92.
}

with the village, belonged instead to the house of Premonstratensians in Kláštor pod Znievom and thus fell under ecclesiastical authority, where the level of learning and familiarity with contemporary religious themes would greatly exceed those typical among the circle of land-owning patrons in Liptov. ${ }^{9}$ The Hungarian academic Mária Prokopp offers only a brief description of the Liptovské Sliače scene as a painting of a woman attacked by monsters. ${ }^{10} \mathrm{In}$ his monograph on medieval wall paintings in Slovakia, Milan Togner expresses his agreement with the conclusions of Biathová and Stejskal. ${ }^{11}$ According to Jozef Kútnik Šmálov, the work is a morality painting on the theme of the Seven Cardinal Sins with Mary Magdalene in the centre. ${ }^{12}$ Ivan Gerát sees the painting as a representation of sin or vice in the form of an allegorical figure but also concedes that the full iconographical significance of this figure has not yet been precisely determined and that it remains open to question whether it will ever be possible to do so. ${ }^{13}$ According to Štefan Valášek, the painting is a personification of a specific Cardinal Sin - gluttony (Gula in Latin). ${ }^{14}$ The information provided for the work in the current List of Monuments in Slovakia is a summary of various hesitant conclusions and academic equivocation over a more precise description of the iconographic subject matter of the painting. ${ }^{15}$ As a conclusion to this overview of opinions on the painting, we should also include the curious information on the website of the Immareal image database (Institut für Realienkunde des Mittelalters und der frühen Neuzeit) which describes the scene as the Temptation of St Anthony. ${ }^{16}$

${ }^{12}$ KÚTNIK ŠMÁLOV, J.: „...myšllienky zostávajü“. Liptovské Sliače 2001, p. 96.

${ }^{13}$ GERÁT, I.: Stredoveké obrazové témy na Slovensku: osoby a príbehy. Bratislava 2001, p. 276.

${ }^{14}$ VALÁŠEK, Š.: Človek a stredoveké nástenné mal'by. Vzt’ah $\mathrm{v}$ dimenzii času (1300 - dodnes) a priestoru (Liptov). In: Staré a nové. Staré jako východisko, či prèkážka: sborník prǒspèvkèu mezinárodni konference studenti doktorských studijnich programu. Eds. NOVÁ, M. - OPATRNÁ, M. Praha 2016, pp. 107-108.

${ }^{15}$ Liptovské Sliače. In: Národné kultúrne pamiatky na Slovensku- okeres Rư̌omberok. Ed.: HALČINOVÁ, K. Bratislava 2008, p. 216.

${ }^{16}$ https://realonline.imareal.sbg.ac.at; Persistent Link: 012690, Accessed 1. 5. 2020. 
Nonetheless, it is possible to state that there is some degree of consensus among all of these experts concerning the basic framework of the iconography of the wall paintings in Liptovské Sliače: the work is a moralising scene, a depiction of sin or vice. Indeed, in our introduction to this contribution, we have described the painting in Rimavske Brezovo in a similar fashion. However, if we find these general statements unsatisfactory and wish to arrive at a more detailed characterisation of the images, we can see that both of these paintings of female figures holding vessels and beset by demons in fact represent the specific motif of a landlady or tavern keeper suffering in Hell. Ondřej Faktor and Jan Dienstbier have drawn attention to this specific compositional theme in their incisive study of images of the Last Judgement which also analyses depictions of the figure of the landlady within this particular context and in a wider geographical framework. ${ }^{17}$ The authors argue that the iconography of depictions of the Last Judgement underwent a change from the early $14^{\text {th }}$ century onwards, with the more universal figures of the heretic, the brute or the adulteress being replaced in Hell by figures of deceitful craftsmen and landladies. Negative depictions of landladies are a manifestation of the misogynistic character of the medieval period and are also based on other contemporary beliefs of the period which saw women as more susceptible to sin. The increased consumption of alcohol in this period was linked with the vice of gluttony but also with improper sexual behaviour which transgressed the principles of medieval Christian morality. Depictions of the figure of the landlady in combination with demons can be found throughout medieval Europe from the early $14^{\text {th }}$ century until the early modern period, and negative portrayals of the character appear in numerous literary sources of the period, particularly in Passion Plays. In their overview of this iconographic subject,

\footnotetext{
${ }^{17}$ FAKTOR, O. - DIENSTBIER, J: Obrázky z pekla. Souvislosti několika vyobrazení Posledního soudu z počátku 14. století. In: Uméní, 63, 2015, No. 6, pp. 434-457.

${ }^{18}$ Ibidem, p. 452.

${ }^{19}$ On the connections between the vice of gluttony, drinking and excrement, see GROLLOVÁ, J. - RYWIKOVÁ, D.:
}

Faktor and Dienstbier also make reference to early modern examples from the territory of present day Slovakia which prove the persistent appeal of the motif - the $16^{\text {th }}$ century western icons of the Last Judgement from Lukov-Venécia and two icons from the Museum of Ukrainian Culture in Svidník which date from the $16^{\text {th }}$ and $17^{\text {th }}$ centuries. ${ }^{18}$ In addition to these examples, we can also include the landlady in Hell which appears on the 1661 icon of the Last Judgement from Bogliarka which is monogrammed by C.Z., now in the collection of the Slovak National Gallery in Bratislava (O 6194/a, b). However, in all of these examples, the paintings of the landladies set upon by demons form only one element of more extensive and complicated multifigural depictions of the Last Judgement. The distinctive character of the iconography of the paintings in Rimavské Brezovo and Liptovské Sliače derives primarily from the isolation of the motif in these works. A comparison with related artworks may also explain why the demon in the Rimavské Brezovo scene appears to be defecating into the barrel - this surprising detail often appears in images in Hell in connection with the punishment of the damned. Excrement is, in effect, a product of the sin of Gluttony, a further consequence of which is the subsequent damnation to Hell, where sinners are punished with drinks laced with demonic excrement. ${ }^{19}$

Comparisons with similar images also allow us to reconstruct the activity of the two naked men in the lower right section of the Rimavské Brezovo painting - with a high degree of likelihood, the scene is a depiction of two gamblers fighting over a game of backgammon..$^{20}$ Similar scenes can be found in, for example, the wall painting of Hell in the Church of St Nicolas in Boletice in the Czech Republic from the first quarter of the $14^{\text {th }}$ century, ${ }^{21}$ the wall paintings from the first third of the $14^{\text {th }}$ century in the tower of Brandis Castle in Maienfeld in Switzer-

Militia est vita hominis: Sedm smrtelných brichui a sedm skutku milosrdenství v literárnich a vizuálních pramenech českého stredověku. České Budějovice 2013, pp. 154-155.

${ }^{20}$ We would like to thank Jan Dienstbier for enabling the identification of the activity of these figures.

${ }^{21}$ FAKTOR - DIENSTBIER 2015 (see note 17), pp. 437-438. 
land, ${ }^{22}$ transfers of wall paintings from Zvolen Castle from around 1480, and also on numerous late-medieval tiles of Czech provenance. ${ }^{23}$

Despite this clarification of the iconography of the wall paintings, one question still remains unanswered: the reason why those who commissioned new wall paintings decided to have the Landlady in Hell painted over with a more iconographically conventional painting of the Passions of Christ only half a century later. The paintings of landladies tormented by demons represent moralising images which criticise an activity and an environment which are in direct contradiction to the foundations of Christian morality. The paintings, positioned by the entrance to the church, use the scene of two naked backgammon players fighting to suggest to the congregation that the tavern environment and the consumption of alcohol will lead to gambling and aggressive behaviour, which will, in turn, pave the way to eternal torment. The preserved paintings in Rimavské Brezovo and Liptovské Sliače are valuable evidence of eschatological concepts and the ways in which they were disseminated in the $14^{\text {th }}$ and $15^{\text {th }}$ centuries: located within the sacred space, the scenes clearly demonstrate specific sinful acts to believers and explicitly connect the performance of deeds in the earthly realm with individual forms of punishment which await the damned in Hell.

This text developed as a part of the VEGA grant project (2/0075/19): Ikonológia charity v mestách strednej Európy-priklad Bratislavy / Iconology of Charity in Central European Cities - Example of Bratislava.

\footnotetext{
${ }^{22}$ RAIMANN, A.: Gotische Wandmalerei in Graubünden: Die Werke des 14. Jahrbunderts in nördlichen Teil Graubünden und im Engadin. Disentis 1983, p. 282.
}

${ }^{23}$ SMOLÁKOVÁ, M.: K ikonografii zobrazenia Bitka dvoch mužov (hráčov). In: Archaeologia historica, 36, 2011, pp. 573-581. 


\title{
The Landlady from Hell. The Iconography of the Medieval Wall Paintings in Rimavské Brezovo and Liptovské Sliače
}

\begin{abstract}
Résumé
The text aims to clarify the iconography of medieval paintings in the churches in Rimavské Brezovo and Liptovské Sliače (Slovakia). Even at first glance, the images draw our attention due to their unusual theme: a woman in a red dress with a white hood upon her head pours liquid from a ceramic flask in her right hand to another vessel which she is holding in her left hand. Both of these paintings of female figures holding vessels and beset by demons represent the specific motif of a landlady or tavern keeper suffering in Hell. The iconography of the Last Judgement underwent a change from the early $14^{\text {th }}$ century onwards, with the more universal figures of the heretic, the brute or the adulteress being replaced in Hell by figures of deceitful craftsmen and landladies. Negative depictions of landladies are a manifestation of the misogynistic character of the medieval period and are also based on other contemporary beliefs of the period which saw women as more susceptible to sin. The increased consumption of alcohol in this period was linked with the vice of gluttony but also with improper sexual behaviour which

transgressed the principles of medieval Christian morality. Depictions of the figure of the landlady in combination with demons can be found throughout medieval Europe from the early $14^{\text {th }}$ century until the early modern period, and negative portrayals of the character appear in numerous literary sources of the period, particularly in Passion Plays. However, in all of these examples, the paintings of the landladies set upon by demons form only one element of more extensive and complicated multifigural depictions of the Last Judgement. The distinctive character of the iconography of the paintings in Rimavské Brezovo and Liptovské Sliače derives primarily from the isolation of the motif in these works. The preserved paintings in Rimavské Brezovo and Liptovské Sliače are valuable evidence of eschatological concepts and the ways in which they were disseminated in the $14^{\text {th }}$ and $15^{\text {th }}$ centuries: located within the sacred space, the scenes clearly demonstrate specific sinful acts to believers and explicitly connect the performance of deeds in the earthly realm with individual forms of punishment which await the damned in Hell.
\end{abstract}

Mgr. Peter Megyeši, PhD.

Centrum vied o umení SAV org. zložka Ústav dejín umenia

Dúbravská cesta 9

SK-841 04 Bratislava

e-mail: peter.megy@gmail.com 